\title{
Anionic Favipiravir in Salt-type Cocrystals with Monoethanolamine and Ethylenediamine
}

\author{
Odil Choriev,* Jamshid Ashurov,** Aziz Ibragimov,* Shukhrat Turaboev,** and \\ Vahobjon SABIROV**,***ं
}

*Institute of General and Inorganic Chemistry, Uzbekistan Academy of Sciences, 100170, Kh. Abdullaev Str., 77a, Tashkent, Uzbekistan

**Institute of Bioorganic Chemistry, Uzbekistan Academy of Sciences, 100125, Kh. Abdullaev Str., 83, Tashkent, Uzbekistan

***Tashkent State Technical University, Almalyk Branch, Ulug'bek Str., 45, 110100, Almalyk, Uzbekistan

\begin{abstract}
Salt-like cocrystals of favipiravir (FVR) with monoethanolamine (MEA) (I) and ethylendiamine (en) (II) have been determined by X-ray crystallography. The crystallographic data are (1), monoclinic $P 2_{1} / c, Z=4, a=12.2433(3)$, $b=22.5400(5), c=7.3223(3) \AA, \beta=106.287(3)^{\circ}, V=1939.6(1) \AA, R_{1}=0.0499$; (II), triclinic $P \overline{1}, Z=2, a=8.5903(12)$, $b=9.4980(10), c=10.0337(13), \alpha=83.464(10), \beta=79.338(11), \gamma=80.665(10) \AA, V=790.90(18) \AA^{3}, R=0.0709$. In both of compounds, FVR is a single charged anion with a deprotonated 2-hydroxyl group. The asymmetric unit of the lattice consists: (1) of two FVR anion and two MEA cations; (2) of two FVR anions and one a double charged en cation.
\end{abstract}

(Received September 30, 2021; Accepted October 28, 2021; Published on web January 10, 2022)

Favipiravir (FVR) is an antiviral medication used to treat influenza in Japan (Fig. 1). It is also being studied to treat a number of other viral infections. Like experimental antiviral drugs $\mathrm{T}-1105$ and $\mathrm{T}-1106$, it is a pyrazinecarboxamide derivative. ${ }^{1}$ It is, however, only indicated for novel influenza (strains that cause more severe disease), rather than seasonal influenza. The mechanism of its actions is thought to be related to the selective inhibition of viral RNA-dependent RNA polymerase. $^{2}$

The possible tautomerism of FVR has been investigated computationally. ${ }^{3}$ It was found that the enol-like form was substantially more stable in aqueous solution than the keto-like form, meaning that FVR likely exists almost exclusively in the enol-like form in aqueous solution (Fig. 2).

An enol form of FVR was found in the crystal structure of FVR. ${ }^{4}$ The crystal structure of FVR has been analyzed in silico research for structural analysis of FVR and its activity against COVID-19.5,6 It was found that four tautomeric structures could be considered to be ligands obtained by density functional theory

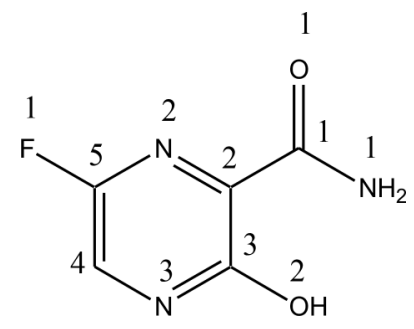

Fig. 1 Chemical formula of FVR.

† To whom correspondence should be addressed.

E-mail: v_sabirov@mail.ru
(DFT) calculations. The crystal structures of the cocrystals of many organic compounds with neutral FVR are already known, ${ }^{6,7}$ but an anionic form of FVR similar to that studied in this work has not yet been known.

This is for the first time obtained and crystallographic studied as an anionic form of FVR, which has been obtained using a basic co-former as monoethanolamine (MEA) and ethylendiamine $(e n)$. The given results can be used to describe the interaction of FVR with the amino acids of a protein molecule.

The purpose of this paper is to study the effects of the salt formation of FVR with the basic molecules MEA and en on its geometric parameters and its conformation. Salts of FVR with MEA (1) and en (2) were prepared by a similar procedure: (1): the reaction of FVR $(0.1 \mathrm{mM}, 0.157 \mathrm{mg})$ and MEA $(0.1 \mathrm{mM}$, $6.11 \mathrm{mg})$, and (2): the reaction of FVR $(0.1 \mathrm{mM}, 6.11 \mathrm{mg})$ and en $(0.1 \mathrm{mM}, 6.01 \mathrm{mg})$, which were dissolved in ethanol $(10 \mathrm{~mL})$. The reaction mixtures were stirred for $15 \mathrm{~min}$ at a temperature of $\sim 60^{\circ} \mathrm{C}$. Both crystals were obtained by slow evaporation of the reaction solutions at the room temperature. The hydrogen atoms of the amino groups in both structures were located on a difference-Fourier map, but other hydrogen<smiles>NC(=O)c1nc(F)cnc1O</smiles>

(a)<smiles>NC(=O)c1nc(F)c[nH]c1=O</smiles>

(b)
Fig. 2 Tautomeric (a) enol and (b) keto forms of FVR. 
atoms were positioned geometrically $(\mathrm{OH}=0.82 \AA$ and $\mathrm{CH}=$ $0.93 \AA$ ) and refined using a riding model, with $U_{\text {iso }}(\mathrm{H})=$ $1.2 U_{\mathrm{eq}}(\mathrm{C})$ and $1.5 U_{\mathrm{eq}}(\mathrm{O})$. Crystal data and details of the

Table 1 Crystal and experimental data for (1) and (2)

\begin{tabular}{|c|c|c|}
\hline Chemical formula: & $\mathrm{C}_{7} \mathrm{H}_{11} \mathrm{~N}_{4} \mathrm{O}_{3} \mathrm{~F}$ & $\mathrm{C}_{11} \mathrm{H}_{10} \mathrm{NOF}$ \\
\hline Formula weight $=$ & 218.20 & 178.53 \\
\hline$T=$ & \multicolumn{2}{|c|}{ 293(2)K } \\
\hline Crystal system: & monoclinic & triclinic \\
\hline Space group: & $P 2_{1} / c$ & $P \overline{1}$ \\
\hline$a=$ & $12.2433(3) \AA$ & $8.5903(12) \AA$ \\
\hline$b=$ & $22.5400(5) \AA$ & $9.4980(10) \AA$ \\
\hline$c=$ & $7.3223(3) \AA$ & 10.0337(13)Å \\
\hline$\alpha=$ & $90^{\circ}$ & $83.464(10)^{\circ}$ \\
\hline$\beta=$ & $106.287(3)^{\circ}$ & $79.338(11)^{\circ}$ \\
\hline$\gamma=$ & $90^{\circ}$ & $80.665(10)^{\circ}$ \\
\hline$V=$ & $1939.60(10) \AA^{3}$ & $790.90(18) \AA^{3}$ \\
\hline$Z=$ & 4 & 2 \\
\hline$D_{\mathrm{x}}=$ & $1.494 \mathrm{~g} \mathrm{~cm}^{-3}$ & $1.125 \mathrm{~g} \mathrm{~cm}^{-3}$ \\
\hline$\mu(\mathrm{Cu} K \alpha)=$ & $1.130 \mathrm{~mm}^{-1}$ & $0.621 \mathrm{~mm}^{-1}$ \\
\hline$F\left(\begin{array}{lll}0 & 0 & 0\end{array}\right)=$ & 912.0 & 282.0 \\
\hline Crystal size $=$ & $0.35 \times 0.35 \times 0.45 \mathrm{~mm}^{3}$ & $0.30 \times 0.35 \times 0.40 \mathrm{~mm}^{3}$ \\
\hline Radiation: & \multicolumn{2}{|c|}{$\mathrm{Cu} K \alpha(\lambda=1.54184 \AA)$} \\
\hline $\begin{array}{l}2 \theta \text { range for data } \\
\text { collection: }\end{array}$ & 7.844 to $152.342^{\circ}$ & 9.002 to $152.38^{\circ}$ \\
\hline Index ranges: & $\begin{array}{l}-14 \leq h \leq 15,-26 \leq k \\
\leq 28,-6 \leq 1 \leq 9\end{array}$ & $\begin{array}{c}-10 \leq h \leq 10,-6 \leq k \leq \\
11,-12 \leq 1 \leq 12\end{array}$ \\
\hline $\begin{array}{l}\text { Reflections } \\
\text { collected }=\end{array}$ & 13436 & 5590 \\
\hline $\begin{array}{l}\text { Independent } \\
\text { reflections = }\end{array}$ & $\begin{array}{l}3991\left[R_{\text {int }}=0.0468\right. \\
\left.\quad R_{\text {sigma }}=0.0362\right]\end{array}$ & $\begin{array}{l}3191\left[R_{\mathrm{int}}=0.0661\right. \\
\left.R_{\mathrm{sigma}}=0.0965\right]\end{array}$ \\
\hline $\begin{array}{l}\text { Data/restraints/ } \\
\text { parameters }=\end{array}$ & $3991 / 0 / 315$ & $3191 / 0 / 238$ \\
\hline $\begin{array}{l}\text { Goodness-of-fit } \\
\text { on } F^{2}=\end{array}$ & 1.068 & 0.985 \\
\hline $\begin{array}{l}\text { Final } R \text { indexes } \\
\qquad[I>=2 \sigma(I)] \text { : }\end{array}$ & $\begin{array}{l}R 1=0.0499, w R 2= \\
\quad 0.1314\end{array}$ & $\begin{array}{l}R 1=0.0568, w R 2= \\
\quad 0.1191\end{array}$ \\
\hline $\begin{array}{l}\text { Final } R \text { indexes } \\
\quad \text { [all data]: }\end{array}$ & $\begin{array}{l}R 1=0.0709, w R 2= \\
\quad 0.1562\end{array}$ & $\begin{array}{l}R 1=0.1085, w R 2= \\
\quad 0.1515\end{array}$ \\
\hline $\begin{array}{l}\text { Largest diff. } \\
\text { peak/hole }=\end{array}$ & $0.27 /-0.31 \mathrm{e}^{-3}$ & $0.27 /-0.31 \mathrm{e}^{-3}$ \\
\hline Data collection: & \multicolumn{2}{|c|}{$\begin{array}{l}\text { "XtaLAB Synergy, Single sorce at home/near, } \\
\text { HyPix3000" }\end{array}$} \\
\hline $\begin{array}{l}\text { CCDC deposition } \\
\text { number: }\end{array}$ & 21087698 & 2108797 \\
\hline
\end{tabular}

structure refinement are presented in Table 1.

The crystalline structure of (1) composed of two FVR- anions and two $\mathrm{MEA}^{+}$cations is shown in Fig. 3a. Both MEA ${ }^{+}$cations are linked with two different $\mathrm{FVR}^{-}$anions through the N7-H... and the $\mathrm{N} 1-\mathrm{H} \cdots \mathrm{O}$ hydrogen bonds. Both $\mathrm{MEA}^{+}$are in a gauche form: the torsion angles O10-C9-C8-N7 equal to -64.0(3)(A) and $-55.2(2)(B)$. Crystal (2) is built from two FVR ${ }^{-}$anions linked to each together by an $\mathrm{H}_{2} \mathrm{en}^{2+}$ cation through $\mathrm{N}-\mathrm{H}$-..O2 hydrogen bonds (Fig. 3b). The $\mathrm{N} 2$ and $\mathrm{N} 3$ atoms participate in the hydrogen bonds N8-H8B $\cdots \mathrm{N} 2 \mathrm{~B}$ and N8-H8C $\cdots \mathrm{N} 3 \mathrm{~B}$, and also in the weak intermolecular bond $\mathrm{C} 4 \mathrm{~B}-\mathrm{H} 4 \mathrm{~B} \cdots \mathrm{N} 3 \mathrm{~A}$.

In both compounds, FVR is in an anionic state with a deprotonated 2-OH-group (Fig. 4). The differential electron density peak does not appear in the vicinity of $\mathrm{OH}$, but appears at $\mathrm{NH}_{2}$-groups. The $\mathrm{C} 3-\mathrm{O} 2$ bond distance is shortened compared with that in crystalline FVR, ${ }^{4} 1.328(2) \AA$, and equal to: $1.287(2)$ and 1.292(2) $\AA$ in (1), and 1.282(4) and 1.276(4) $\AA$ in (2). The C3-N3 bond distance is equal to 1.355(3) in (1) and 1.378(3) in (2), while it is $1.340(2) \AA$ in FVR. ${ }^{4}$ A comparison of these values of the interatomic distances shows that the C3-N3 bond is elongated compared with 1.306(3) $\AA$ in crystalline FVR. Thus, these values of the interatomic distances show that an anionic FVR is in the following tautomeric form shown in Fig. 2.

A negative charge of the FVR anion should be located at the $\mathrm{N} 3$ atom. Instead of intramolecular $\mathrm{O} 2-\mathrm{H} \cdot \cdots \mathrm{O} 1$ hydrogen bond, a new intramolecular $\mathrm{N} 1-\mathrm{H} \cdot . \mathrm{O} 2$ hydrogen bond is formed. The carboxamide group is rotated one-half revolution around the $\mathrm{C} 1-\mathrm{C} 2$ bond in that case. The torsion angle N1-C1-C2-N2 is equal to $-117.3(2)$ and $-179.9(2)$ in (1), and, $-172.4(3)$ and $-177.9(3)$ in (2).<smiles></smiles>

Fig. 4 Anionic FVR with deprotonated 2-OH-group.

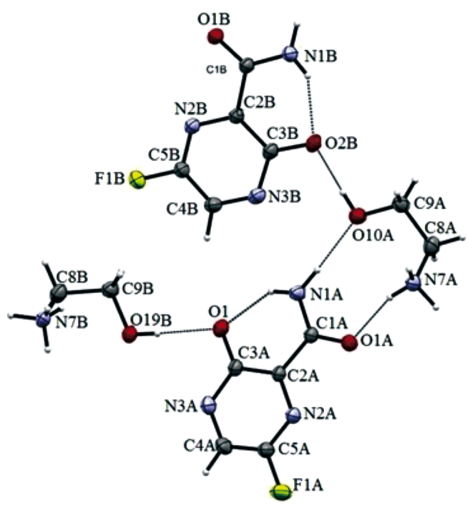

(a)

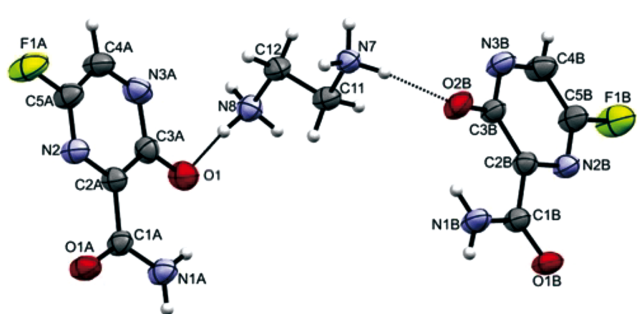

(b)

Fig. 3 Molecular structure of (I) (a) and (II) (b) showing with displacement ellipsoids at the $35 \%$ probability level. 
In the given salt-type cocrystals, an anionic form of FVR with the deprotonated 2-OH group has been found. Instead of an intramolecular $\mathrm{O} 2-\mathrm{H}$... $\mathrm{O} 1$ hydrogen bond, a new intramolecular $\mathrm{N} 1-\mathrm{H} \cdots \mathrm{O} 2$ hydrogen bond is formed. The carboxamide group in both structures is rotated one-half revolution around the $\mathrm{C} 1-\mathrm{C} 2$ bond.

\section{Acknowledgements}

The authors to thank the Ministry of the Science and Innovation of the Republic of Uzbekistan for financial supporting by performing given work.

\section{Supporting Information}

All geometrical parameters of the molecule and all hydrogen bonds are presented in Tables $\mathrm{S} 1-\mathrm{S} 4$, Figs. S1 and $\mathrm{S} 2$ in
Supporting Information.

\section{References}

1. Y. X. Du and X. P. Chen, Clin. Pharm. Therap., 2020, 108, 242.

2. K. Shiraki and T. Daikoku, Pharm. Therapeutics., 2020, 209, 107512

3. L. Antonov, Theor. Chem. Acc., 2020, 139, 145.

4. F. Shi, Z. Li, L. Kong, Yu. Xie, T. Zhang, and W. Xu, Drug. Discov. Ther, 2014, 8, 117.

5. K. Harismah and M. Mirzaei, Adv. J. Chem. B, 2020, 2, 55 .

6. P. Deka, D. Gogoi, Kh. Althubeiti, D. R. Rao, and R. Thakuria, Cryst. Growth Des., 2021, 21, 4417.

7. A. S. Goloveshkin, A. A. Korlyukov, and A. V. Vologzhanina, Pharmaceutics, 2021, 13, 139.

8. X. Wang, L. Wang, Ch. Yao, G. Xie, Sh. Song, H. Li, Y. Qu, and X. Tao, Cryst. Growth Des., 2021, 21, 3807. 